\title{
Possibilities of Using Al-Si-Mg Alloys with Higher Fe Content for Demanding Castings
}

Dana Bolibruchová, Lukáš Richtárech

Department of Technological Engineering, Faculty of Mechanical Engineering, University of Žilina, Univerzitná 1, 010 26, Slovak Republic, Email: danka.bolibruchova@fstroj.uniza.sk

The present article describes the effect of adding iron into melt, and its impact on the microstructure, chemical composition and mechanical properties of AlSi7Mg0.3 alloy. Higher iron content is typical of the so-called secondary alloy, which becomes increasingly used by a growing number of manufacturers in the production process of high-quality castings. The behaviour of AISi7Mg0.3 alloy with high Fe content has not been scientifically investigated and sufficiently described, therefore working with secondary alloy is very problematic when focusing on high-sophistication castings for the automotive industry. In general, iron is unwanted in aluminium alloys, and its content should be kept as low as possible. The only exception is the process of pressure die casting where we can tolerate iron content up to $1 \mathrm{wt}$. \%. In gravity casting of Al-Si-based alloys, the critical iron content changes mainly depending on the silicon content. The experimental part of this article investigates the impact of gradual addition of iron into AISi7Mg0.3 alloy on the content of the main alloying elements such as, in particular, Si and Mg. In order to eliminate the negative effect of iron in the alloy, we used in the experiment the correctors $\mathrm{Ni}$ and $\mathrm{Cr}$ in the form of AlNi20 and AlCr20 master alloys.

Keywords: AlSiMg alloy, iron, correctors

\section{References}

[1] TAYLOR, J.A. (2012). Iron-containing intermetallic phases in Al-Si based casting alloys. In: Procedia Materials Science, Vol. 1, pp. $19-33$.

[2] TAYLOR, J.A. (2004). The effect of iron in Al-Si casting alloys. In: 35th Australian Foundry Institute National Conference, pp. 148 - 157, Adelaide, South Australia.

[3] DINNIS, C.M., TAYLOR, J.A., DAHLE, A.K. (2005). As-cast morphology of iron-intermetallics in Al-Si foundry alloys. In: Scripta Materialia, Vol. 53, pp. 955 - 958.

[4] CAO, X., CAMPBELL, J. (2006). Morphology of Al5FeSi phase in Al-Si cast alloys. In: Materials Transactions, Vol. 47, No. 5, pp. $1303-1312$.

[5] KUMARI, S.S.S., PILLAI, R.M., RAJAN, T.P.D., PAI, B.C. (2007). Effects of individual and combined additions of $\mathrm{Be}, \mathrm{Mn}, \mathrm{Ca}$ and $\mathrm{Sr}$ on the solidification behaviour, structure and mechanical properties of Al-7Si-0.3Mg0.8Fe alloy. In: Material Science and Engineering A, Vol. 460-461

[6] BOLIBRUCHOVÁ, D., RICHTÁRECH, L. (2013): Effect of adding iron to the AlSi7Mg0.3 (EN AC 42100 , A356) alloy. In: Manufacturing Technology, Vol. 13, No. 3, pp. 276-281. ISSN 1213-2489

[7] TILlOVA, E., CHALUPOVA, M. (2009). Structural analysis of Al-Si cast alloys, pp. 191. EDIS, Žilina.

[8] BOLIBRUCHOVA, D., ZIHALOVA, M. (2013). Possibilities of iron elimination in aluminium alloys by vanadium. In: Manufacturing technology, Vol. 13, No. 3, pp. 289 -296. ISSN 1213-2489

[9] BOLIBRUCHOVÁ, D., BRU゚NA, M. (2014): Influencing the crystallization of secondary alloy AlSi6Cu4 with strontium. In: Manufacturing Technology, Vol. 13, No. 1, ISSN 1213-2489

[10]PASTIRČÁK, R. (2015): Effect of low pressure application during solidification on microstructure of AlSi alloys. In: Manufacturing Technology, ISSN 1213-2489. - Vol. 14, no. 3 (2014), s. 397-402.

[11]PETRIK, J., HORVATH, J. (2011). The iron correctors in Al-Si alloys. In: Annals of faculty engineering Hunedoara, Vol. 9, No. 3, pp. $401-405$.

[12]MONDOLFO, L.F. (1943). Metallography of Aluminium Alloys. pp. 351. USA.

[13]ZHANG J, FAN Z, WANG Y Q, ZHOU B. Microstrucral refinement in Al-Mg2Si in situ composites [J]. Journal of Materials Science Letters, 1999, 18(10): 783-784.

[14] SEIFEDDINE, S. (2007). The influence of Fe on the microstructure and mechanical properties of cast Al-Si alloys: Literature review, Vilmer project. Jönköping University.

[15] MOUSTAFA, M.A. (2009). Effect of iron content on the formation of $\beta$-Al5FeSi and porosity in Al-Si eutectic alloys, Journal of Materials Processing Technology, 209(1), 605-610, DOI 10.1016/j.jmatprotec.2008.02.073

[16]TILlOVÁ, E., CHALUPOVÁ, M., HURTALOVÁ, L., BONEK, M., DOBRZANSKI, L.A, (2011). Structural analysis of heat treated automotive cast alloy, Journal of Achievements in Materials and Manufacturing Engineering/JAMME, 47(1), 19-25 